Jurnal Riset Kesehatan, 9 (1), 2020, 1 - 5

DOI: $10.31983 /$ jrk.v9i1.5387

Jurnal Riset Kesehatan

http://ejournal.poltekkes-smg.ac.id/ojs/index.php/jrk

\title{
UNMET NEED OF HEALTH FACILITIES IN BOGOR REGENCY
}

\author{
Adhitya Kusuma Wahyunugroho *) \\ Badan Pusat Stastistik; Direktorat Pengembangan Metodologi Sensus dan Survei \\ Jln. Dr.Sutomo No. 6- 8; Jakarta Pusat ; DKI Jakarta
}

\begin{abstract}
The existence of health facilities (fasilitas kesehatan/faskes) especially in district levels is very suitable to reduce the number of people with impaired level of health. For this reason, a targeted program which aims to reduce the number of unmet needs in areas that have high population, high rate of increase and high density is badly needed. This is in line with the characteristics of Bogor regency as a research locus. The method used in this research was a combination method between tabular analysis (statistics) and spatial data. The combination combined locations with low unmet need health facilities resulting from a causality of 2 (two) variables, the number of residents and the number of health facilities, so that the precise and accurate results could be obtained. The conclusion from the spatial analysis is that 19 out of 40 sub-districts in Bogor regency were indicated unmet need for low health facilities. Although this research was very simple, the result of this study is very important because it can be used as a guideline for the development of health facilities, especially community health centers (Puskesmas) in Bogor regency.
\end{abstract}

Keywords: Spatial Analysis; Tabular Analysis; Geo-tagging; Public health center (Puskesmas)

\section{Introduction}

The development of health facilities is intended to provide services for residents with impaired health (Badan Pusat Statistik (BPS)/ the Central Bureau of Statistics, 2018). However, the existence of these facilities is not yet made use of by residents for various reasons, such as the absences of costs for treatment and transportation, the long waiting -time or the unavailability of the nearest health facilities that can be reached so that it is hard for treatment.

The indicator to measure the number of people who are sick but not treated because of those above factors is called unmet need for health services (Badan Pusat Statistik (BPS)/ the Central Bureau of Statistics, 2018). One step to overcome this problem appropriately and quickly is to increase the development of health facilities, especially for administrative areas that are close to resident population i.e. districts (Ministry of Health, 2015). According to the

\footnotetext{
*) Corresponding Author (Adhitya Kusuma Wahyunugroho) E-mail: adhitfhaf11081978@gmail.com
}

Ministry of Health,(2015), information on this image in the past three years has decreased in line with high population growth.

Bogor Regency was chosen as the location of the study because this region has a unique characteristic that is this area has a very wide area, high population growth rate, high population density and high disrupted population (BPS Bogor Regency, 2018). However, the number of health facilities is still limited and not evenly spread in all districts.

Researches related to unmet need for health facilities were already conducted by several researchers, for example (Septarini, 2017), (Ariyanti, 2017), (Masseria, 2009), (Hwang, 2018) and (OJ, 2016). Unlike those researches, this study used different and new method to be used in determining the value of unmet need facilities, especially Puskesmas (public health center) at district level, which was a combined method using tabular data (statistics) and spatial data in the form of spatial distribution geo-tagging points (spatial). 


\section{Method}

Determination of the location of the unmet need can be declared successful and accurate if the determination of parameters/ variables and methods used are accurate and precise. There are 3 (three) parameters used and all of them are generated from the census and survey activities carried out by the Central Bureau of Statistics (BPS).

Those three parameters are population data (BPS Bogor Regency, 2018), data on the number cases of health problems (BPS Bogor Regency, 2018) and data on geo-tagging points of the health infrastructure obtained from the WILKERSTAT application that were carried out in range of time of 2018-2019

There are 2 (two) stages of the method used in this study in order to produce precise and accurate results. In the outline, this study used a combination of methods whereas in an analysis, this study used 2 analysis: statistical and spatial.

The first stage is the statistical analysis test phase. According to researchers, the statistical tests needed to be done are regression test and correlation between parameters. It is necessary to find out which parameters have high interdependence values. Regression analysis method is needed to find out the relationship between two variables (parameters), while the correlation analysis method is used to see patterns in one variable (parameter) based on the other parameters (Arikawati, 2016). So from both analysis, we will get a model that has high causal relationship (Arikawati, 2016).

The second stage is spatial analysis. This is a newly used method, namely the method of "exploratory regression". To get the value of regression and spatial autocorrelation, we use the Moran's method all of which are found in the tool in ArcGIS 10.6 software.
In this method, the regression value is seen from AICc (Akaike Information Criterion) value and from AdjR2 value. Based on research from Fathurahman, (2009), the value of AICc is a part of OLS (Ordinary Least Squares) method used to determine the best regression value, especially to forecast purposes (forecasting or referencing). Recommended value is the smallest value of all models used (Sinharay, 2010).

While AdjR2 ( $R$ squared adjusted) value is used to see a regression pattern, whether increasing number of samples will increase the regression value (Hession and Moore, 2011). If the adjR2 value approaches the value of 1 along with addition of samples numbers, then the model is said to be the best model (Frost, 2019).

The next thing to do in this study is to determine the value of spatial autocorrelations (SA) which is obtained using Moran's method. Wang (Wang, 2019) in his research said that this method is used to find two or more spatial data that are close together and have similarities.

The next step is to determine the criteria for unmet need for a location. The determination of ideal ratio data for each category of health facility infrastructure is needed. This determination is in accordance with Septarini's thesis, (2017) saying that the ideal health ratio is 1 Puskesmas for 30,000 population.

By using spatial analysis, "select by attributes", the unmet need location will be obtained by conducting a query process using population data and data on the number of geo-tagging points of Puskesmas infrastructure from the WILKERSTAT application. This data collection was conducted in 2018-2019.

\section{Result and Discussion}

The results obtained from determining the regression and correlation values can be seen in Table 1.

Table 1. Regression results and correlations among parameters

\begin{tabular}{lcc}
\hline \multicolumn{1}{c}{ Variable/Parameter } & Regression & Correlation \\
\hline $\begin{array}{l}\text { Number of populations with number of infra health } \\
\text { points }\end{array}$ & 0,575299 & 0,763573 \\
$\begin{array}{l}\text { Number of populations with number of infra } \\
\text { Number of populations with number of infra health } \\
\text { points }\end{array}$ & 0,257565 & 0,50063 \\
\hline \multicolumn{1}{c}{ Source: Data processing } & & 0,3277 \\
\end{tabular}

The regression and autocorrelation values through a spatial approach can be seen in table 2 .
From the table, the results are similar as regression and correlation values from table 1. 
Jurnal Riset Kesehatan, 9 (1), 2020, 3 - 5

DOI: $10.31983 /$ jrk.v9i1.5387

Table 2. Spatial regression values and spatial autocorrelations

\begin{tabular}{lcc}
\hline \multicolumn{1}{c}{ Variable/Parameter } & $\begin{array}{c}\text { Spatial } \\
\text { regression }\end{array}$ & $\begin{array}{c}\text { Spatial } \\
\text { autocorrelation }\end{array}$ \\
\hline $\begin{array}{l}\text { Number of populations with number of infra health } \\
\text { points }\end{array}$ & 0,568297 & 0,899938 \\
$\begin{array}{l}\text { Number of populations with number of infra health } \\
\text { points }\end{array}$ & 0,238028 & 0,000101 \\
$\begin{array}{l}\text { Number of populations with number of infra health } \\
\text { points }\end{array}$ & 0,568297 & 0,238105 \\
\hline
\end{tabular}

From the two tables above, it can be seen that the influence of the population has a great impact to the number of health infrastructure points. In other words, the more population existed, the more health facilities must be available

After obtaining the used parameters, the next step is to determine the location of unmet need. From this spatial method we get results as seen in image 1 below.

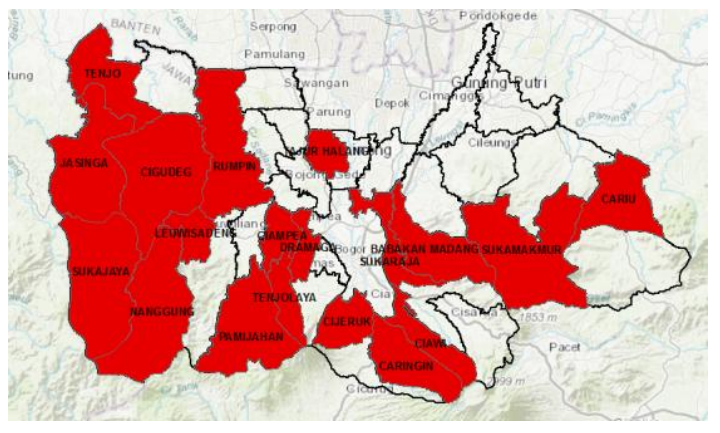

Image 1. Unmet need location distribution map for PUSKESMAS infrastructure

(Source: Data Processing)

Based on image 1 above, the red colors on the map are 19 out of 40 districts in Bogor Regency that need health facilities i.e. Puskesmas, both for new infrastructure and infrastructure additions. The 19 districts can be seen in table 3 below.

These findings are very precise and accurate because this study included more detailed elements of accuracy in taking geo-tagging in its application. This is in accordance with an article from Miller, (2013). This application for geo-tagging is called the WILKERSTAT application, which functions to take and photograph all infra points throughout Indonesia up to the RT/neighborhood/hamlet level. This application is more accurate and precise because of additional information from the chiefs/leaders of SLS/environmental/hamlet regarding information on the presence of health facilities in their areas.

Table 3. List of district unmet need for Puskesmas health facility

\begin{tabular}{cl}
\hline No & \multicolumn{1}{c}{ District } \\
\hline 1 & Nanggung \\
2 & Pamijahan \\
3 & Sukajaya \\
4 & Leuwisadeng \\
5 & Dramaga \\
6 & Tajur Halang \\
7 & Rumpin \\
8 & Babakan Madang \\
9 & Jasinga \\
10 & Cijeruk \\
11 & Ciawi \\
12 & Tenjolaya \\
13 & Tenjo \\
14 & Sukamakmur \\
15 & Cariu \\
16 & Sukaraja \\
17 & Cigudeg \\
18 & Caringin \\
19 & Ciampea \\
\hline : Data processing
\end{tabular}

The difference of this research from the previous ones is that the results obtained in this study are aimed at calculating the lack of Puskesmas health facilities in each district in Bogor regency, whereas in previous studies the results are only aimed at calculating the ratio (Septarini, 2017).

Although the results of this analysis are only focused on health facilities for public health center (Puskesmas) and only at district levels, when viewed from the map, the distribution of population is mixed with the data on health infrastructure points (Puskesmas) at regency level, the same pattern can be seen, which is only centered in the region close to the Bogor city and Depok city.

Information is spread as in Image 2 below. In other words, the development is only focused in areas close to the city (Nugraha, 2012). 


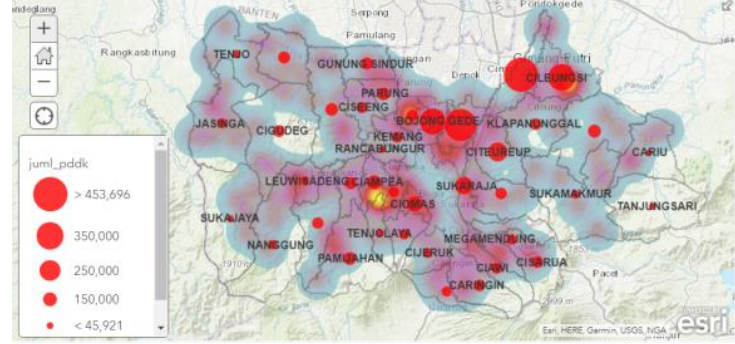

Image 2. Map of population distribution with the level of availability of infra health centers (source: data processing)

This can also be seen in Image 3 below which shows a map of population distribution combined with data points of health infrastructure (hospitals) in one regency.

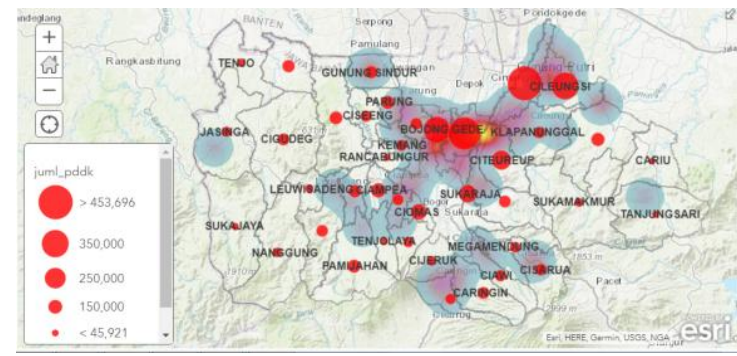

Image 3. Map of population distribution with hospital infra-health availability

(source: data processing)

\section{Conclusion and Suggestion}

A number of health facilities are needed especially in Bogor regency. This is because this region has a large population, the highest number of districts, the most extensive area and a high rate of population growth in the West Java province.

Therefore, information about unmet need for health facilities is very much needed in the determination of policies, especially in terms of overcoming the number of health cases in this regency. The conclusions of this study based on the above analysis are as follows:

a. The combination of statistical and spatial analytical methods is very helpful in determining the precise and accurate number of unmet need.

b. Regression and correlation values are needed for the initial analysis test as a guide to which variables/parameters are interconnected and influential, where these variables/parameters will be used in spatial analysis.

c. There are 19 out of 40 districts in the study location where the unmet need of health facilities numbers are still low.

d. The pattern of distribution of health facilities is only centered in areas close to urban areas. This is very burdensome for people who live far from urban areas who want to seek treatment.

e. There is a great need of additional health facilities and new health facilities development, in this case is Puskesmas, in several districts that have less unmet need numbers.

\section{The suggestion:}

a. There is a need of developing larger and more complete health facilities in terms of the completeness of medicines, such as hospitals, in several regions based on the ideal ratio for hospitals, which is 1 hospital is for 100.000 population, and also a need of medical personnel

b. Provision of data on the number of health facilities must always be updated based on conditions in the field.

c. The process of taking infra-health points (geo-tagging) must always be updated on an ongoing basis.

d. The use of tools or gadgets for infrared point recording should use a detailed level of accuracy ( $<5$ meters).

e. For further research in the framework of infrastructure development or construction, new analytical methods are needed for the development of new health facilities that are friendly to community by using the "find near location" or "network analyst" method by looking at the elements of nearest mileage and access road that can be traversed.

\section{Acknowledgements}

I would like to thank to the Bogor Regency BPS for providing data on population and number of health cases, the Mapping Team in PPS Subdit of the Central Bureau of Statistics (BPS) who amazingly produced a spatial-based application for mapping boundaries and took points and photos for all infrastructure categories throughout Indonesia.

Last but not least, special thank also goes to the teaching team of KTI (Karya Tulis Ilmiah/ Scientific Writing) which have always given encouragement to complete this research. 


\section{References}

Arikawati, Erlina. (2016, Agustus 30). Regresi dan Korelasi. Jakarta, Jakarta, Indonesia. Retrieved from http:/ / erlinaarikawati.blogspot.com/20 16/08/regresi-dan-korelasi.

Ariyanti, L. (2017). Ketersediaan sumber daya kesehatan dan kebutuhan KB tidak terpenuhi (unmeet need): analisis tingkat provinsi. Berita Kedokteran Masyarakat, 33, 49-54.

Badan Pusat Statistik. (2018). Publikasi Statsitik Kesejahteraan Rakyat. Jakarta: Badan Pusat Statistik.

BPS Kabupaten Bogor. (2018). Daerah Dalam Angka. Bogor: Badan Pusat Statistik Kabupaten Bogor.

Fathurahman, M. (2009). Pemilihan model regresi terbaik mengunakan metode Akaike's Information Criterion. 4, 37-41.

Frost, J. (2019, Oktober 25). How to Interpret Adjusted R-Squared and Predicted $R$-Squared in Regression Analysis. Retrieved Oktober 25, 2019, from Statistics By Jim: https://statisticsbyjim.com/regression/i nterpret-adjusted-r-squared-predicted-rsquared-regression/

Hwang, J. (2018, July 16). Understanding reasons for unmet health care needs in Korea: what are health policy implications? BMC Health Services Research, 557.

Kementerian Kesehatan. (2015). Rasio dan Jumlah Puskesmas di Indonesia. Jakarta:
Kementrian Kesehatan.

Masseria, S. A. (2009, November 19). Unmet need as an indicator of health care access. EuroHealth, 7-9.

Miller, S. (2013, Mei 8). Geotagging brings new meaning to Location in scientific observations. United States of America: Sciece Scene.

N.Moore, S. H. (2011). A spatial regression analysis of the influence of topography on monthly rainfall in East Africa. 31, 1440-1456.

Nugraha, A. P. (2012). Evaluasi Pengembangan Wilayah dalam Meningkatkan Kawasan Agropolitan di Kabupaten Tabalong. Jurnal Ilmu Politik dan Pemerintahan Lokal, 1, 93-106.

OJ, L. (2016). Unmet Health Services Needs Among US Children with Developmental Disabilities Associations with Family Impact and Child Functioning. Journal of Developmental $\mathcal{E}$ Behavioral Pediatrics, 712-723.

Septarini, W. (2017). Distribusi Spasial Puskesmas di kota Banjarmasin. Skripsi, 1-10.

Sinharay, S. (2010). An Overview of Statistics in Education. ScienceDirect, 1-11.

Wang, W.-C. (2019). An Application of the Spatial Autocorrelation Method on the Change of Real Estate Prices in Taitung City. International Journals of Geo_information, 8, 1-20. 